\title{
The External Role of Public Managers in Improving the Quality of Community Services through Delivery to Mentawai Ethnic
}

\author{
$1^{\text {st }}$ Wahib Assyahri ${ }^{1}, 2^{\text {nd }}$ Dasman Lanin ${ }^{2}, 3^{\text {rd }}$ Boni Saputra $^{3}$ \\ \{ wassyahri.wa@gmail.com $^{1}$, dasmanlanin@gmail.com ${ }^{2}$, bonisaputra@fis.unp.ac.id $^{3}$ \} \\ Department of Magister Public Administration, Universitas Negeri Padang, Padang, Indonesia ${ }^{1}$ \\ Department of Public Administration, Universitas Negeri Padang, Padang, Indonesia ${ }^{2,3}$
}

\begin{abstract}
The purpose of this study was to determine the influence of the external role of public managers in improving the quality of community services through delivery to Mentawai ethnic. The research method uses a quantitative approach. The population in this study were the native Mentawai society. Sampling in this study used the Slovin formula with an error rate of 5\% and produced 148 samples of the community. Determination of the sample using the Accidental Sampling technique. Collecting data using a questionnaire distributed to respondents with measurements using a Likert scale. The data obtained were then analyzed using path analysis. The results showed that 1) the external role variable of managers affected service quality, 2) the variable of delivery affected the quality of service, 3 ) the variable of the external role of the manager affected delivery, 4) the variables of service quality and delivery simultaneously affected service quality.
\end{abstract}

Keywords: Role of Public Managers, Service Quality, Delivery, Mentawai Society.

\section{Introduction}

The government is the foremost bureaucratic organization that deals with public services. Improving the quality of public services is one of the policy issues in the current era of bureaucratic reform. This becomes very important considering the quality of public services since the bureaucratic reform was rolled out, there have been improvements but have not increased significantly. The performance of government bureaucracy can simply be measured by assessing the good and bad quality of public services. Measuring the performance of public services is a very important aspect to see the achievement of the implementation of services to the community.

Good public services certainly have quality standards that must be met. To realize good public services, the government must place the number and quality of existing staff and apparatus accordingly and have an understanding of good public services. Thus, good and targeted public servants will bring the bureaucracy closer to the community. Serving society well is the responsibility of all government agencies. Thus, every employee in a government agency must serve the community and learn how to improve skills to serve [1]. In service skills, 
this includes mastery of the knowledge of the services provided, because this will show the public that the employee in the government agency is a professional in the field of Public Service Management.

UU No. 25 of 2009 concerning Public Services in Article 1 paragraph (1), public services are activities or a series of activities in the framework of meeting service needs by statutory regulations for every citizen and resident for the provided goods, services, and administrative services by public service providers [1]. Then the quality of public service is the totality of the ability of service providers to provide services for products (goods or services) or administrative services to customers or the public, which can meet needs and can provide satisfaction to customers based on conformity with expectations and reality received by customers or community [2]. The quality of public services is the level of excellence between expected service and perceived service by the community, both in the form of public goods and services [3]. Based on the above understanding, it can be concluded that service quality is the service that is received and felt by the community as expected or exceeds their expectations from service providers in providing services for products in the form of goods or services.

Measurement of service quality can be measured through indicators consisting of reliability, responsiveness, assurance, empathy, and tangibles [4]. Then Tjiptono in [5] Expected service and perceived service are determined by the dimension of service quality which consists of five dimensions, namely: 1) Tangible, consisting of physical facilities, equipment, personnel, and communication; 2) Reliability, consisting of the ability of the service unit to create the promised service appropriately; 3) Responsiveness, a willingness to help consumers are responsible for the quality of services provided; 4) Assurance, including the knowledge, ability, politeness, and trustworthiness of the staff, free from danger, risk or doubt; 5) Empathy, which includes the ease of making good communication relationships, personal attention, and understanding the needs of customers.

The provision of public services by government officials an implication of the function of the state apparatus as public servants to realize people's welfare. Therefore, the position of government officials in the delivery of public services is very strategic because it will determine the extent to which the government can provide the best possible service to the community. In conditions of dynamic community development, the public bureaucracy must be able to provide public services that are more professional, effective, simple, transparent, open, timely, responsive, and adaptive as well as being able to build human quality in the sense of increasing the capacity of individuals and society to actively determine the future in front of itself [6]. For this reason, managers need to know the motives or needs and different behavior of the government apparatus they lead. Managers have a very important role to influence and mobilize employees in achieving company goals. Mintzberg in [7] indicators of external roles of managers consist of 1) Figurehead, 2) Liaison, 3) monitor, 4) spokesperson, 5) entrepreneur, and 6) negotiator.

According to Lovelock and Wright in [8] service organizations are seen as a system consisting of a service operation system and a service delivery system. In a service operation system, it is a component contained in the entire service organization system, where inputs are processed and elements of service products are created through human resource components and physical components. In the service delivery system, relates to when, where, and how services are delivered to customers, including system elements in service operations and other things that are presented to other consumers. Then the Delivery of services is the spearhead of service. In connection with the arrival of product service to the user, it will have an impact on people's satisfaction regarding the quality assessment of the approach to the service association. The false organization's internal capabilities with the ability to increase the level of customer 
satisfaction in providing services or the approach are to use the concept of service delivery. Delivery of services is the purpose of the service design process by analyzing the various alternatives that will be used to realize the arrival of service to customers [9]. Delivery measurement indicators consist of 1) the final outcome, 2) the way the service kept its promises, 3) the way the service handled any problems, and 4) significant commitment beyond oneself [7].

[11] Tested the Local Government Service model for TQM-based Customer Satisfaction in three public sectors, namely the Immigration sector, the Industry and Labor sector, and the Population and Civil Registry sector, the results show that this model is consistent and shows significant effects. Significant between internal customer satisfaction (employees) with 6 variables between or service transactions (delivery, timeliness, professionalism, information, staff attitude, internal organization politics) and vice versa also significant service transactions with external customer satisfaction.

This study focuses on ethnic background, namely the external role of public managers in reminding the quality of Mentawai community services through the delivery variable because local wisdom has recently become an aspect of settling conflicts in public management. Ali Farazman's Sound Governance (strong government) greatly strengthens this local government. Relevant research on the efficacy of ethnic values includes [11] who found that communities in all Nagari in Minangkabau feel more comfortable being managed with ethnic cultural values than top-down management by the government. Then [12] [13] shows that identity leadership tends to have a positive impact as the foundation for the initial commitment and capabilities of village leaders and managers. Appreciation for the demands of local identity and culture at the rural level as social capital in government management needs to be developed continuously as a model. Furthermore, research by [9] shows that there is a significant influence of $66.6 \%$ on delivery on service quality at the Department of Manpower and Industry in Padang City.

Based on the explanation that the researcher has described, the researcher is interested in researching with the title The External Role of Public Managers in Improving the Quality of Community Service through Delivery to Ethnic Mentawaians. The formulation of the main problems in this study are 1) Is there a variable influence on the external role of managers on service quality ?; 2) Is there an effect of the delivery variable on service quality ?; 3) Is there any influence of manager's external role on delivery?

\section{Methodology}

The method used in this research is quantitative. The location of this research is in Mentawai. The variables used in this study are Service Quality (X1), Delivery (X2), and Community Satisfaction (Y). The population in this study was the Mentawai people. The sample in this study amounted to 148 respondents who were determined using a proportional random sampling technique. The data collection techniques used a documentation study and questionnaire. The data in this study were analyzed using path analysis. Furthermore, the data that has been collected is processed through the SPSS version 21 program.

The research hypothesis can be formulated as follows: 
1. First Hypothesis

Ha1: There is a significant influence between the external role of managers on service quality H01: There is no significant influence between the external role of managers on service quality

2. Second Hypothesis

Ha2: There is a significant influence between delivery on service quality

H02: There is no significant effect between delivery on service quality

3. Third Hypothesis

Ha3: There is a significant influence between the external role of managers on delivery

H03: There is no significant influence between the external role of managers on delivery

The stages in this research are data collected using documentation study and questionnaires distributed to the public. After the community filled out all the questionnaires, data tabulation was carried out. Then the tabulated data is processed using the SPSS version 21 program. After that, the processed data can be analyzed and hypothesis testing is carried out.

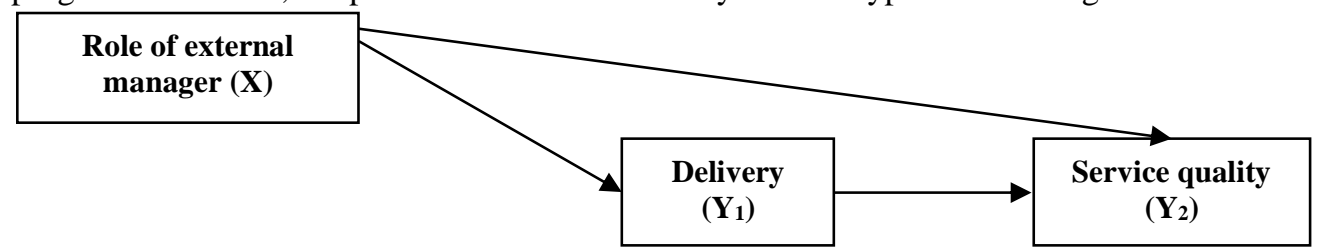

Figure 1 Conceptual Framework

\section{Finding and Discussion}

Based on the data from the questionnaire obtained by the researcher, the respondent profile is presented as follows.

Table 1 Profile of Research Respondents

\begin{tabular}{|c|c|c|c|c|c|c|c|}
\hline Gender & & Education & & Age & & Employment & \\
\hline \multirow[t]{2}{*}{ Male } & 78 & $\begin{array}{l}\text { Elementary school/ } \\
\text { Equivalent }\end{array}$ & 52 & $<20$ & 10 & Entrepreneur & 3 \\
\hline & & $\begin{array}{l}\text { Junior High School/ } \\
\text { Equivalent }\end{array}$ & 39 & $21-30$ & 42 & Farmer & 78 \\
\hline \multirow[t]{4}{*}{ Female } & 70 & $\begin{array}{l}\text { Senior High } \\
\text { School/Equivalent }\end{array}$ & 44 & $31-40$ & 61 & Housewifery & 55 \\
\hline & & Diploma I / II / III & 9 & $41-50$ & 28 & Tourism & 5 \\
\hline & & Bachelor & 1 & $>50$ & 7 & Employees & 7 \\
\hline & & Masters/Spesialist & 3 & & & & \\
\hline Total & 148 & Total & 148 & Total & 148 & Total & 148 \\
\hline
\end{tabular}

Source: 2020 Research Data Processed Results

Based on the data in Table 1 above, it can be seen that the gender of male respondents is more than female respondents, where the number of male is 78 people, while the number of female is 70 people. From the aspect of education, the most respondents are Elementary School and equivalent as many as 52 people and at least 1 person is a Bachelor. From the age of the most respondents in the range of 31-40 years were 61 people and the least was 50 years and over 1 person. Of the respondents' occupations the most were farmers as many as 78 people and 
the least were self-employed, namely 3 people. Then the results obtained based on data processing are presented below.

\subsection{The Influence of Manager's External Role on Service Quality}

The following are the results of data processing on the influence of the external role of managers on service quality.

Table 2 The Influence of Manager's External Role on Service Quality

\begin{tabular}{|c|c|c|c|c|c|}
\hline Model & $\mathrm{R}$ & R Square & $\begin{array}{c}\text { Adjusted R } \\
\text { Square }\end{array}$ & $\begin{array}{c}\text { Std. Error of } \\
\text { the Estimate }\end{array}$ & $\begin{array}{c}\text { Durbin- } \\
\text { Watson }\end{array}$ \\
\hline 1 &, $702^{\mathrm{a}}$ &, 493 &, 490 & 8,63889 & 2,202 \\
\hline
\end{tabular}

a. Predictors: (Constant), The Manager's External Role

b. Dependent Variable: Service Quality

From table 2, it is found that the value of the Adjusted R Square variable for the external role of managers on service quality is 0.490 or it can also be interpreted that the variable external role of managers has a magnitude of influence of $49 \%$ on the variable of service quality, while the rest is influenced by other variables outside this study.

Table 3 ANOVA ${ }^{a}$

\begin{tabular}{|ll|l|l|l|l|l|}
\hline \multicolumn{1}{|c|}{ Model } & \multicolumn{1}{c|}{$\begin{array}{c}\text { Sum of } \\
\text { Squares }\end{array}$} & df & Mean Square & F & Sig. \\
\hline $1 \quad$ Regression & 10611,708 & 1 & 10611,708 & 142,190 &, $000^{\mathrm{b}}$ \\
Residual & 10896,042 & 146 & 74,630 & & \\
Total & 21507,750 & 147 & & & \\
\hline
\end{tabular}

a. Dependent Variable: Service Quality

b. Predictors: (Constant), The Manager's External Role

The test results in table 3 ANOVA show a significance value of 0.000 . This indicates that the external role of managers has a significant effect on service quality. Because the significance of the test value is less than 0.05 , it can be concluded that the magnitude of the influence of the external role of managers on service quality is $49 \%, 100 \%$ reliable.

\section{Effect of Delivery on Service Quality}

The following are the results of data processing the effect of delivery on service quality.

Table 4 Effect of Delivery on Service Quality Model Summary ${ }^{b}$

\begin{tabular}{|c|c|c|c|c|c|}
\hline Model & $\mathrm{R}$ & $\mathrm{R}$ Square & $\begin{array}{c}\text { Adjusted R } \\
\text { Square }\end{array}$ & $\begin{array}{l}\text { Std. Error of } \\
\text { the Estimate }\end{array}$ & $\begin{array}{c}\text { Durbin- } \\
\text { Watson }\end{array}$ \\
\hline 1 &, $628^{\mathrm{a}}$ &, 395 &, 391 & 9,44256 & 1,793 \\
\hline
\end{tabular}

a. Predictors: (Constant), Delivery

b. Dependent Variable: Service Quality 
From table 4, it is found that the Adjusted R Square value of the delivery variable on service quality is 0.391 or it can also be interpreted that the delivery variable has a magnitude of influence of $39.1 \%$ on the service quality variable, while the rest is influenced by other variables outside this study.

Table 5 ANOVA ${ }^{\mathrm{a}}$

\begin{tabular}{|ll|l|l|l|l|l|}
\hline \multicolumn{1}{|c|}{ Model } & \multicolumn{1}{|c|}{$\begin{array}{c}\text { Sum of } \\
\text { Squares }\end{array}$} & df & Mean Square & F & Sig. \\
\hline 1 & Regression & 8490,104 & 1 & 8490,104 & 95,221 &, $000^{\mathrm{b}}$ \\
& Residual & 13017,646 & 146 & 89,162 & & \\
Total & 21507,750 & 147 & & & \\
\hline
\end{tabular}

a. Dependent Variable: Service Quality

b. Predictors: (Constant), Delivery

The test results in table 5 ANOVA show a significance value of 0.000 . This indicates that delivery has a significant effect on service quality. Because the significance of the test value is less than 0.05 , it can be concluded that the magnitude of the effect of delivery on service quality is $39.1 \%$, $100 \%$ reliable.

\section{Effect of Manager's External Role on Delivery}

The following are the results of data processing on the influence of the external role of managers on delivery.

Table 6 The Effect of Manager's External Role on Delivery

\begin{tabular}{|c|c|c|c|c|c|}
\multicolumn{7}{c|}{ Model Summary $^{\mathbf{b}}$} \\
Model & $\mathrm{R}$ & R Square & $\begin{array}{c}\text { Adjusted R } \\
\text { Square }\end{array}$ & $\begin{array}{c}\text { Std. Error of } \\
\text { the Estimate }\end{array}$ & $\begin{array}{c}\text { Durbin- } \\
\text { Watson }\end{array}$ \\
\hline 1 & $529^{\mathrm{a}}$ &, 280 &, 275 & 2,52257 & 2,036 \\
\hline
\end{tabular}

a. Predictors: (Constant), The Manager's External Role

b. Dependent Variable: Delivery

From table 6, it is found that the value of Adjusted R Square for the variable external role of managers on delivery is 0.275 or it can also be interpreted that the variable external role of managers has a magnitude of influence of $27.5 \%$ on the delivery variable, while the rest is influenced by other variables outside this study. 
Table 7 ANOVA ${ }^{a}$

\begin{tabular}{|ll|l|l|l|l|l|}
\hline \multicolumn{2}{|c|}{ Model } & \multicolumn{1}{c|}{$\begin{array}{c}\text { Sum of } \\
\text { Squares }\end{array}$} & df & Mean Square & F & Sig. \\
\hline 1 & Regression & 360,626 & 1 & 360,626 & 56,672 &, $000^{\mathrm{b}}$ \\
& Residual & 929,050 & 146 & 6,363 & & \\
& Total & 1289,676 & 147 & & & \\
\hline
\end{tabular}

a. Dependent Variable: Delivery

b. Predictors: (Constant), The Manager's External Role

The test results in table 7 ANOVA show a significance value of 0.000 . This indicates that it turns out that the external role of managers has a significant effect on delivery. Because the significance of the test value is less than 0.05 , it can be concluded that the magnitude of the influence of the external role of managers on delivery is $27.5 \%, 100 \%$ reliable.

Based on the results of the test analysis of each exogenous variable against the endogenous variables and the path analysis model used by the author, the path coefficient can be presented as illustrated below.

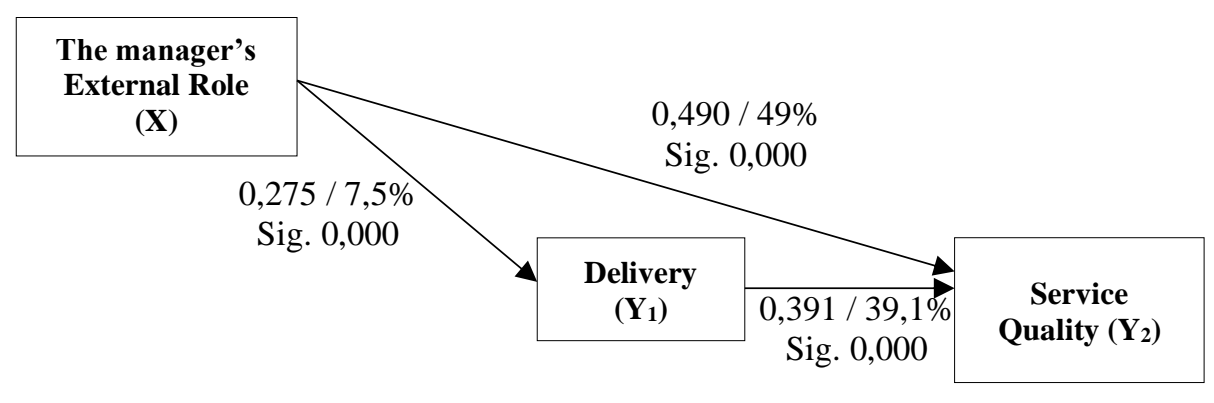

Figure 2 Entering the Path Coefficient into the Model

The following is a summary of the results of the path analysis test

Table 8 Summary of Path Analysis Test Results

\begin{tabular}{|c|c|c|c|}
\hline No & Description & $\begin{array}{l}\text { Direct } \\
\text { Effect }\end{array}$ & $\begin{array}{l}\text { Indirect } \\
\text { Effect }\end{array}$ \\
\hline 1 & $\begin{array}{l}\text { The influence of the external role of manager }(\mathrm{X}) \text { on } \\
\text { service quality }\left(\mathrm{Y}_{2}\right)\end{array}$ & 0,490 & \\
\hline 2 & The influence of delivery $\left(\mathrm{Y}_{1}\right)$ on service quality $\left(\mathrm{Y}_{2}\right)$ & 0,391 & \\
\hline 3 & $\begin{array}{l}\text { The influence of the manager's external role }(\mathrm{X}) \text { on } \\
\text { delivery }\left(\mathrm{Y}_{1}\right)\end{array}$ & 0,275 & \\
\hline 4 & $\begin{array}{l}\text { The manager's external role }(\mathrm{X}) \text { on service quality } \\
\left(\mathrm{Y}_{2}\right) \text { through delivery }\left(\mathrm{Y}_{1}\right)\end{array}$ & & $66,6 \%$ \\
\hline
\end{tabular}

Source: 2020 Research Data Processed Results 
The indirect effect of the variable external role of managers on service quality through delivery is the direct effect of $X-Y_{1} \times Y_{1}-Y_{2}(0.275 \times 0.391)=0.666 / 66.6 \%$.

\section{Discussion}

Based on the results of research we can see that the external role of the manager has a significant effect on the service quality variable. This is evidenced by the results of data processing using SP SS 21 software, it is found that the significance value of the external role variable of managers on service quality is $0.000<0.05$. Based on these results it can be understood that the variable external role of managers has a significant influence on service quality with a level of confidence reaching $100 \%$. So that the hypothesis Ha is accepted.

The amount of influence that the external role variable of managers has on service quality is $49 \%$. This is obtained based on the Adjusted R Square value of 0.490. These results indicate that the better and bigger the role of the external manager is given that is felt by the community in Mentawai.

Then, based on the results from the analysis of the effect of delivery on service quality, show that the delivery variable has a significant effect on the service quality variable. This results of data processing using SP SS 21 software that the significant value of the delivery variable on service quality is found to be $0.000<0.05$. Based on these results it can be understood that the delivery variable has a significant influence on service quality with a level of confidence reaching $100 \%$. So that the hypothesis Ha is accepted.

The amount of influence that the delivery variable has on service quality is $39.1 \%$. This $39.1 \%$ value was obtained based on the Adjusted R Square value of 0.391. These results indicate that the better and the bigger the delivery is given to the community, the better and greater the quality of service felt by the people in Mentawai.

Furthermore, based on the results of the calculation of the analysis that has been carried out, the results obtained are that the manager's external role variable has a significant effect on the delivery variable. This results is obtained from data processing using SP SS 21 software show that the significance value of the external role of the manager variable on delivery is 0.000 $<0.05$. Based on these results, it can be applied that the manager's role variable has a significant effect on delivery with a level of confidence reaching $100 \%$. So that the hypothesis $\mathrm{Ha}$ is accepted.

The amount of influence that the external role variable of managers has on delivery is $27.5 \%$. This $27.5 \%$ value was obtained based on the Adjusted R Square value of 0.275 . These results indicate that the better and bigger the role of the external manager is given, the better and bigger the delivery will be felt by the community in Mentawai.

The results of this study are in line with research conducted by [9], the results of the research show that there is a significant effect of $66.6 \%$ on delivery on service quality at the Department of Manpower and Industry in Padang City. Then this research is by that stated by [10] there is a significant influence between service and determinants of satisfaction.

The role of public managers is very much needed in providing the best and quality form of service to the community. Various policies and actions as well as the external role of public managers will affect the form of services provided to the community which in turn will affect various factors of public satisfaction, one of which is delivery. For this reason, public managers, in this case, the government, must be able to fulfill every desire of the community for their needs in getting the best service. 


\section{Conclusion}

Based on the results of this study it can be concluded that there is a significant influence of the external role of the manager on service quality by $49 \%$ for the people in Mentawai. Then there is a significant effect of delivery on service quality of $39.1 \%$ for the Mentawai people. Furthermore, there is a significant influence of the external role of the manager on delivery of $27.5 \%$ for the people in Mentawai. The significance value of each of these variables is 0.000 .

The public manager in this case is the government must know and understand the needs of the community and strive for how the community's needs in getting quality services can be met. The role of government is very important in providing, quality services and fulfilling the need for public services for the community. Quality services will increase community satisfaction so that they can generate positive perceptions for the community towards the government.

\section{References}

[1] W. Assyahri and M. Vaguita, "Evaluasi Penggunaan Aplikasi Sistem Keuangan Desa (Siskeudes) di Nagari Kayu Tanam Kecamatan 2x11 Kayu Tanam," Nakhoda J. Ilmu Pemerintah., vol. 18, no. 2, pp. 79-91, 2019.

[2] M. H. dan H. A. M. R. Indonesia, Undang-Undang RI No. 25 Tahun 2009 tentang Pelayanan Publik. 2009.

[3] A. Duriat and R. Vaughan, "Pengaruh Kualitas Pelayanan E-Ktp Terhadap Kepuasan Masyarakat Di Kecamatan Kramatmulya," Kebijak. J. Ilmu Adm., vol. 11, no. 1, pp. 1827, 2020, doi: 10.23969/kebijakan.v11i1.2231.

[4] P. A. Ramadhani, "Pengaruh Kualitas Website Dalam Layanan E-Kios Terhadap Kepuasan Masyarakat Di Kelurahan Nginden Jangkungan Surabaya," JPAP J. Penelit. Adm. Publik, vol. 4, no. 1, pp. 355-372, 2018, doi: 10.30996/jpap.v4i1.1278.

[5] Irwantoro, "Pelayanan Akta Kelahiran pada Dinas Kependudukan dan Catatan Sipil Kota Surabaya," Matra Pembaruan, vol. 2, no. 1, pp. 49-58, 2018, doi: 10.21787/mp.2.1.2018.49-58.

[6] N. Nurhadi, "Konsep Pelayanan Perspektif Ekonomi Syariah," EkBis J. Ekon. dan Bisnis, vol. 2, no. 2, p. 137, 2020, doi: 10.14421/EkBis.2018.2.2.1100.

[7] Nuriyanto, "Rembug Pelayanan Publik (RPM) Sebagai Aktualisasi Pelayanan Publik Berlandaskan Demokrasi Pancasila (Rembug of The Public Services as an Actualization of The Public Services Base On The Democracy of Pancasila)," J. Konstitusi, no. 25, 2015.

[8] D. Lanin, "Kepuasan Warga terhadap Perkhidmatan Kerajaan Tempatan Padang Panjang," Universiti Utara Malaysia, 2010.

[9] N. M. Wibowo, "Strategi Pengembangan Pelayanan Rawat Inap Puskesmas Berbasis Service Delivery System," EKUITAS (Jurnal Ekon. dan Keuangan), vol. 17, no. 3, p. 337, 2017, doi: 10.24034/j25485024.y2013.v17.i3.2256.

[10] W. Astuti, D. Lanin, and Syamsir, "The Effect of Employee Satisfaction on Service Quality Through Delivery and Professionalism in Labor and Industrial Agency of Padang City," in Proceedings of the International Conference On Social Studies, Globalisation And Technology (ICSSGT 2019) The, 2020, vol. 458, no. Icssgt 2019, pp. 40-50, doi: 10.2991/assehr.k.200803.006.

[11] M. B, S. Syamsir, and D. Lanin, "The effect of employee professionalism, employee motivation and effectiveness of technology information on service population and civil 
registration on agam regency," J. Apl. IPTEK Indones., vol. 2, no. 3, pp. 122-126, 2018, doi: 10.24036/4.32140.

[12] D. Lanin, "Kebijakan Desentralisasi dan Pemuliaan Nilai Kultural-Etnis dalam Birokrasi (Kasus: Model Otomisasi Nagari di Sumatera Barat)," J. Ilmu Adm. dan Organ. Bisnis dan Birokrasi, vol. 14, no. 1, 2006.

[13] D. Lanin, "Local Governance Management in West Sumatera: A Reinforcement Model of Identity Leadership and Culture on Rural,” DEMOKRASI, vol. 7, no. 1, pp. 31-50, 2008.

[14] D. Lanin and N. Hermanto, "The effect of service quality toward public satisfaction and public trust on local government in Indonesia," Int. J. Soc. Econ., vol. 46, no. 3, pp. 377 392, 2019, doi: 10.1108/IJSE-04-2017-0151. 